\title{
Comparing Craft and Culinary Practice in Africa: Themes and Perspectives
}

\author{
Cameron Gokee • Amanda L. Logan
}

Published online: 12 June 2014

(C) Springer Science+Business Media New York 2014

The collection of papers presented in this special issue of the African Archaeological Review emerged out of a session entitled "Making Meals, Producing Pots: Comparing Craft and Culinary Practice in Africa" held at the 2012 Society for Africanist Archaeology (SAfA) biennial meetings in Toronto. While archaeologists working in Africa and elsewhere have often focused on either crafts or foodways, participants in the session sought to explore vital points of intersection between these strongly material and deeply embodied technologies of daily life. Building upon several excellent case studies (e.g., Ashley 2010; Gosselain 2010; Haaland 2007, 2012; Lyons and D'Andrea 2003; Maclean and Insoll 1999, 2003), we considered the ways in which craft and culinary practices together entail cultural knowledge, skills, and techniques for transforming raw materials into food, drink, pots, metals, cloth, and other sundries consumed and displayed on a day-to-day basis. We also explored the nuanced ways in which foods and crafts shape diverse subjectivities and materialize social distinctions between women and men, chiefs and commoners, and foreigners and locals, even as shared practices and tastes act as the glue that binds disparate groups together. The contributions to this issue further highlight how knowledge of crafting and farming practices, as well as their products, are enrolled in the exercise of political power. We take the opportunity in this editorial introduction to expand briefly on these and related themes that weave through the following ethnoarchaeological and archaeological case studies comparing craft and culinary practices in Africa.

\section{Gokee $(\bowtie)$}

Department of Anthropology, Appalachian State University, ASU Box 32016, Boone, NC 28608-2016, USA

e-mail: gokeecd@appstate.edu

\section{A. L. Logan}

Department of Anthropology, Northwestern University, 1810 Hinman Ave., Evanston, IL 60208, USA e-mail: amanda.logan@northwestern.edu 


\section{From the "Big Sequence" to Operational Sequences: Situating Crafts and Foodways in Africa}

Craft and subsistence practices have long been vital to the archaeological study of social processes, actions, and experiences. For archaeologists working in the early to mid-twentieth century, the tools and food remains discarded by past people allowed for basic interpretations of craft technologies and subsistence economies, which in turn formed the first rungs on a "ladder of inference" toward the study of ancient political formations and ideologies (e.g., Childe 1951; Hawkes 1954). Processual archaeologists subsequently challenged this interpretive hierarchy of economy, politics, and ideology (Binford 1962), although many continued to view foods and crafts as two separate, and fundamentally economic, domains within complex cultural systems (e.g., Clarke 1978; Flannery 1972). Recognizing the limits of earlier economic perspectives, over the past few decades, archaeologists have increasingly deployed craft and culinary remains in the study of identity and status (Costin and Wright 1998; Gumerman 1997; Smith 2006; Stark 1998; Twiss 2007), cultural memory and tradition (Mills and Walker 2008; Pauketat 2001a), and diverse forms of cultural interaction and entanglement (Gosden 2004; Knappett 2011; Lightfoot et al. 1998; Silliman 2001; Stahl 2002). Importantly, many archaeologists today share a poststructural view of material practice that emphasizes embodied habitus and subjective agencies in the dialectical production, and potential transformation, of social structures (Dobres and Robb 2000; Hegmon 2003; Pauketat 2001b). This view challenges us to overcome analytical and interpretive divisions of labor and consider craft and culinary practices as inseparable fields of social action.

African archaeology is well-positioned to contribute to and benefit from a more holistic approach to craft and cuisine for at least two reasons. First, a legacy of scholarship shaped by the so-called Big Sequence has put subsistence and craft production at the center of several long-standing debates surrounding the chronology and causes of major biological, technological, and social transformations over the past two and a half million years (Stahl 1999a). For example, research on bio-cognitive evolution during the Early to Middle Stone Ages has focused heavily upon the complexity and dynamism of human foraging strategies, documented by faunal assemblages, and associated (craft) technologies of food procurement, particularly chipped stone and bone tools (e.g., Barham and Mitchell 2008; Clark 2011; DominguezRodrigo 2002; McBrearty and Brooks 2000; McCall and Thomas 2012). Similarly, research on the gradual emergence of herding and farming subsistence regimes during the Late Stone Age has focused on identifying early domesticates and associated technologies of food production and preparation, namely ground stone tools and pottery (e.g., Breunig and Neumann 2002; Casey 2005; Clark and Brandt 1984; Jousse 2006; Neumann 2003). While the archaeology of the Iron Age has attended to the origins, causes, and consequences of metallurgical technologies in Africa up to the midsecond millennium AD (Killick 2004; Schmidt 1996; Vogel 2000), research on this and subsequent periods has also looked at important intersections among interregional exchange, urbanism, and increasingly complex subsistence and craft economies (see DeCorse 2001; Kusimba and Kusimba 2003; LaViolette and Fleisher 2005; MacEachern 2005; McIntosh and McIntosh 1988; Monroe 2013; Stahl 2004). Alongside the archaeology of "foods, metals, and towns" (Shaw et al. 1993), a comparative 
study of crafts and foodways therefore stands to illuminate the ways in which everyday experiences and practices underwrote change and continuity in household and political economies, social identities, religious rituals and ideologies, and processes of global entanglement across Africa.

Second, ethnoarchaeological research in Africa has long offered a means to discover the material dimensions of human behaviors and beliefs in the present with implications for inferences about the past, albeit one modeled on the Big Sequence (see summaries in Atherton 1983; MacEachern 1996). Research on "Iron Age" crafts such as pottery and metallurgy, for example, has focused mainly on the ways in which these intersect with local and regional economies (e.g., David and Hennig 1972; LaViolette 2000), social boundaries (e.g., Dietler and Herbich 1998; Larick 1991), cultural traditions (e.g., Gallay and Huysecom 1989; Gosselain 2000; Mayor 2010; Sall 2005), and symbolic systems (e.g., Childs 1991; David et al. 1988; Haaland 2007; Rowlands and Warnier 1996). Meanwhile, ethnoarchaeological research on foodways has looked mainly at the "Stone Age" subsistence strategies of historic foragers (e.g., Kusimba 2003; O’Connell et al. 1988; Wiessner 1982), including pathways to domestication (e.g., D'Andrea and Wadge 2011; Hildebrand 2003; Lyons and D'Andrea 2003). As ethnoarchaeology has come of age alongside other "contemporary" archaeologies over the past decade, scholars have become less concerned with addressing archaeological problems and more interested in exploring recent social institutions and subjectivities through the lens of material culture (e.g., González-Ruibal 2006; Lyons 2007; Richard 2011). Regardless of theoretical or methodological orientation, several ethnoarchaeological studies across Africa have underlined the profound connection between crafts and foodways as people employ ceramic, metal, and lithic tools to produce, store, prepare, and serve food (Arthur 2006; David 1998; Hamon and Le Gall 2013; Lyons 2007; Lyons and D'Andrea 2003) or deploy embodied culinary techniques to make the aforementioned tools (Arthur 2010; Gosselain 2010). Yet such studies remain in the minority, with most focusing on the evidence and interpretation of either craft or culinary activities rather than critical comparisons between the two.

Taking our lead from past contributions and contemporary currents in the archaeology and ethnoarchaeology of Africa, we argue that the methodological and theoretical integration of craft and food studies provides one avenue for reframing unanswered questions as well as engaging with new interpretive paradigms. In the remainder of this introduction, we highlight four themes addressed through a more holistic approach to craft and culinary practices by the contributors to this issue. First, we consider the theoretical inseparability of craft and culinary practice in everyday life. Second, we outline the methodological implications for a comparative study of craft and cuisine. Third, we examine the ways in which craft and culinary practices intersect in the negotiation of social identities and distinctions, particularly those associated with gender, class, race, and ethnicity. Finally, we suggest that the comparative study of crafts and cuisine can offer a more nuanced vision of local, regional, and global political economies.

\section{Theme 1: Craft and Cuisine in Everyday Life}

One theme to emerge from the concurrent study of craft and culinary practices is their fundamental inseparability in everyday life - that fluid assemblage of material, social, 
and cultural elements experienced and enacted by people on a day-to-day basis (De Certeau 1984). At a practical level, people invariably use craft goods to produce, prepare, and consume food while simultaneously incorporating plant and animal products into their crafts. In many rural African contexts, for example, people use iron hoes both to cultivate fields and to dig clay for ceramic vessels. These latter, in turn, find use for storing, cooking, and serving food, and they often incorporate the residues of domesticated plants and animals as temper. In some cases, these functional relations and residues allow archaeologists to directly infer or identify food production from tools crafted in the past (e.g., Amblard and Pernès 1989; Manning et al. 2011). In other cases, ethnoarchaeological (e.g., Henrickson and McDonald 1983) and archaeological (Ashley 2010; Maclean and Insoll 1999; McIntosh 1995) studies make use of vessel forms to deduce culinary functions and transformations, an approach which Cameron Gokee (this issue) uses as a starting point to explore food preparation techniques in the region of Upper Senegal.

Craft and culinary practices further overlap in the actual individuals and groups who carry them out. Since many craftspeople in Africa are part-time specialists with significant responsibilities as cooks and/or farmers, they may habitually transfer some tools and techniques from one technological domain to the other (Gosselain 2010:197). As Amanda Logan and Dores Cruz (this issue) discuss, women living in the Banda region of west-central Ghana are responsible for both pottery-making and food preparation, so it is not surprising that they employ similar tools and techniques in both sorts of activities. Every day and across the seasons, part-time craft producers must further juggle the conflicting opportunity costs of various food-related and craft-related activities to determine how best to spend their time. The resulting calculus is not wholly economic; it lies firmly embedded within social relations of power and identity extending from the household and community to regional polities and beyond-points to which we return below.

Everyday life comprises not only the seemingly mundane acts of food preparation and craft production but also the ideologies and values that these acts work to reproduce. Several contributors to this issue draw upon ethnoarchaeological case studies to explore the ideological dimensions of food and craft practices, including production, use, and discard. John Arthur and Diane Lyons, for example, each discuss the ways in which craft production incurs social stigma for specific groups of craftspeople in Ethiopia. At the same time, craft specialists in Africa, particularly blacksmiths, often hold ritual and practical knowledge essential to the control of liminal substances and transformative processes such as social and sexual reproduction (e.g., Childs and Killick 1993; Herbert 1993; McNaughton 1988; Schmidt 1996). This symbolic power is not limited to craft specialists but can also be marked and made by the consumption of certain food preparations, as Haaland (2007) describes for porridge and beer. Moving beyond functionalist approaches to pottery use in this issue, Katherine Grillo shows that certain kinds of vessels are tightly bound to religious beliefs among pastoralists in Kenya, while Diane Gifford-Gonzalez argues that divergent patterns of discard reveal variability in the perceptions of craft and food refuse among pastoralists in Kenya and Tanzania, perceptions that further differ from Western views of refuse as "unclean."

In one way or another, all the papers in this issue illustrate the deep interconnections - some subtle, some less so-among crafts and foodways in the practices of 
everyday life. This inseparability should challenge us both to consider material remains as evidence of multilayered practices and to explore how such practices work to perpetuate, transform, or resist broader social processes and cultural structures.

\section{Theme 2: Comparative Methods}

Ethnoarchaeologists may observe and discuss the intersections of craft and culinary practice in people's everyday lives, but archaeologists must infer the nature of these intersections by comparing multiple kinds of textual and material evidence, including ceramic, metallurgical, lithic, botanical, and faunal datasets. As many of the authors in this special issue comment, these different datasets are usually analyzed independently by specialists, all too often with little conversation among them. Two of our aims have been therefore to encourage dialogue between experts, as in the case of the three coauthored papers, and to cross-analyze different kinds of material remains within specific contexts and sites. Here, we outline the units of comparison and theoretical approaches that authors have found appropriate for a more holistic study of craft and culinary practices.

Object-based approaches work from the object "out" (Appadurai 1986:5) to explore how the production, use, and discard of specific tools (such as culinary equipment) intersect with foods, and vice versa. Studies of craft technologies in Africa, particularly pottery, routinely employ the methodological framework of chaine opératoire to tease out specific technical choices and their response to broader cultural institutions and traditions (e.g., Dietler and Herbich 1998; Gosselain 2010). Insofar as they tend to focus on single types of crafts, most of these studies focus minimal attention on the possible significance of intersections with the tools and practical knowledge of other technologies. The papers by Arthur and Grillo in this issue, however, illustrate the potential for comparing across chaînes opératoires to consider how pottery and ground stone technologies articulate both economically and culturally with subsistence regimes, patterns of food storage, and cooking techniques. As we discuss further below, these sorts of comparisons may yield valuable insight into past labor dynamics and social boundaries.

Object biographies offer a complementary perspective on how tools and other crafts accrue value and impinge upon social structures throughout the course of their "social lives" (Appadurai 1986; Kopytoff 1986; Stahl 2010). In Africa, this object-based approach has proven particularly useful for the study of exchange goods such as beads and metals that circulated within the cultural conjunctures and global entanglements of the past several centuries (e.g., Gijanto 2011; Ogundiran 2002; Richard 2010; Stahl 2002). Nevertheless, the biographies of pottery vessels, ground stone implements, and other craft goods may highlight associated practices of food production and consumption, particularly where specialized studies of use wear, phytoliths, and other microscopic data can point to patterns of everyday use (see discussions in papers by Arthur and Grillo, this issue). The discard of materials at the end of their lifecycle, a process which Gifford-Gonzalez (this issue) provocatively calls "spent," can also yield insight into how people perceived the everyday and/or special practices associated with craft objects and foods. Keeping in mind how different kinds of materials are deposited, and at what stages in their lifecycle, is also critical for comparing craft and culinary 
residues; burnt seeds represent a different kind of activity and tempo (cooking, shortterm) than do grinding stones (grinding, long-term) (Atalay and Hastorf 2006).

The study of refuse disposal highlights the need to situate craft objects and food remains within broader material assemblages and depositional contexts. Assemblagebased approaches make use of site- or phase-wide patterns across archaeological datasets that, after accounting for taphonomic processes, can be interpreted as past activities and contextualized as social practices. Although many archaeologists compare assemblages as a matter of course, often without specific theoretical justification, an explicit focus on common cleavages or divergences can help to strengthen or expand interpretations initially derived from one body of data or another (Fogelin 2007; Johnson 2011; Wylie 1985). Archaeological studies of pottery function, for example, often base their interpretations on ethnographically observable categories such as "wet" and "dry" cooking vessels (see Gokee, this issue), but further comparison with botanical and faunal data could help to trace particular dishes or even entire cuisines.

Some of these culinary connections can be found by starting with an object and following it out to all of the possible connections, but there is also interesting potential to compare different classes of things - for example, the adoption of new foods and prestige goods. One framework that shows promise for this type of scaling up builds on Hebdige's "cartographies of taste" as deployed in archaeology by Ann Stahl (2002), which involves mapping how different kinds of crafts and foods are consumed over time and space. Another approach, grounded in the communities of practice literature (e.g., Lave 1991; Minar and Crown 2001; Wallaert-Pêtre 2001; Wendrich 2012), focuses on how learning communities develop through apprenticeship and the subsequent sharing of practical knowledge. The challenge is in deciphering how communities of practice corresponding to different technologies (e.g., pottery, food preparation) map onto one another in material terms. Ingold's (1993) notion of taskscape that highlights the interrelatedness of daily tasks with one another and their temporalities (see Roddick 2013; Logan and Cruz, this issue) provides another explanatory possibility.

Context-based approaches rely upon the spatial, temporal, and depositional context of craft and food remains to decipher past social practices and processes (e.g., Joyce 2008). A considerable literature on feasting, processions, and religious ceremonies, for example, seeks to identify and interpret depositional contexts resulting from the display and consumption of abundant staples and delicacies alongside craft products such as pottery, textiles, iron, copper, and ritual paraphernalia (Dietler 2001; Fleisher 2010; Insoll et al. 2009; Norman 2010). These special events provide sharp resolution on how both foods and material goods were used to negotiate social identity and status in singular or short-term events (see Monroe and Janzen, Gijanto and Walshaw, this issue). Focus on a specific space-time locus may be one of the few times that archaeologists gain access to specific "meals" or "cuisines," but this more holistic understanding requires attention to how foods were prepared, something which can be accessed through bone taphonomy (Gifford-Gonzalez, Monroe and Janzen, this issue), use wear (Arthur, this issue), or specialized archaeobotanical techniques such as phytolith analysis that make typically invisible parts of the process visible. As Gifford-Gonzalez (this issue) observes, many foods and craft objects can even unleash ritual power as they are "spent" and deposited into or withheld from the archaeological record (see also Insoll 2010; Stahl 2008). 
One enduring challenge to comparison is the varied ways that craft and culinary practice are understood and accessed in ethnoarchaeological vs. archaeological contexts. Several of the individual papers as well as the organization of this issue adopt a comparative approach between the ethnographic present and points in the archaeological past, while others ask archaeological questions of ethnographic data. This temporal "tacking back and forth" (Stahl 2001; Wylie 1989) is critical for establishing the dynamic nature of craft and culinary practice instead of making assumptions of continuity. While archaeological resolution of day-to-day life will always remain more distorted than the present, the use of multiple lines of evidence allows for stronger arguments (Fogelin 2007; Johnson 2011; Stahl 1993; Wylie 1985). Importantly, the act of comparing different kinds of data may shift our focus to alternate explanations or variables. For example, in the SAfA session that led to this issue, only one paper (Lyons) used gender as an analytical frame of reference, but in the course of developing their arguments for this issue, three additional papers (Gokee, Logan and Cruz, Monroe and Janzen) adopted this as a primary focus. This suggests that comparing craft and culinary practice is a particularly appropriate tool for analyzing gender and other socially constructed categories.

\section{Theme 3: Social Identities and Distinctions}

Comparing multiple classes of craft and culinary data can help archaeologists to coax out social boundaries and categories that, in addition to gender, include ethnicity and class (e.g., Brumfiel 1992, 2006; Costin and Wright 1998; Díaz-Andreu et al. 2005; Gero and Conkey 1991; Jones 1997; Richard and MacDonald 2014; Stark 1998; Twiss 2007). Such practices are strong indicators of social boundaries in part because the acts of making food, pots, and metals are learned techniques that are transmitted from person to person, and the "proper" uses of such goods are often vigilantly maintained within cultural groups. Attention to practice as a fundamental building block in social life complicates archaeological interpretations of social boundaries as falling along contemporary lines. The comparison of craft and culinary practices, as an analytical method, allows us to contribute to this discussion by honing in on the diverse array of social groupings and boundaries that result when we view such agglomerations from the ground, hearth, or pottery vessel "up." The results do not necessarily indicate social groups such as ethnic groups or castes that we might recognize from contemporary sources, but instead, more flexible, nuanced identities that shift over time (e.g., Croucher and Wynne-Jones 2006; Smith 2004). Our broader comparative project, then, aims to situate historically these diverse identities and subjectivities in the past and present.

The need to historicize contemporary social structures, rather than assume their timeless persistence in the past and present, is based in part on critiques that developed within feminist anthropology and archaeology. Much of this literature targeted the uncritical use of modern-day gender roles to understand past gender dynamics, such as the association of men with hunting or women with gathering (Conkey and Spector 1984; Gero and Conkey 1991; for Africanist examples, see Kent 1998; Wadley 1997; see also Stahl 1993; Wylie 1985). By recognizing that the content and form of gendered identities change across time and space, it becomes possible to explore the historical 
production and negotiation of gender roles in the past (Brumfiel and Robin 2008; Croucher 2007; Joyce 2000). A similar critique has been made of archaeological interpretations of past social boundaries more broadly, which tend to be rooted in modern understandings of contemporary social action and rarely capture the possible breadth of past subjectivities (Smith 2004). The challenge, then, is to capture gender (and other) identities without relying on the ethnographic present for assigning their content - a move made possible, in part, through the comparison of craft and culinary practices. Lyons (this issue), for instance, points out that craft and culinary techniques may perpetuate subjectivities not easily reducible to binary gender roles when potters employ masculine techniques for mining clay, and male potters employ feminine techniques for "cooking" iron in their smithies. Attention to the interrelationship of tasks typically assigned to women (i.e., cooking) and how they interact with other tasks less marked by gender (i.e., farming) in "gendered taskscapes" provides another approach to addressing past gender as a dynamic, rather than as an historical constant (Logan and Cruz, this issue).

Much like the perception of gender as a bounded, timeless unit, colonial projects of classification and postcolonial interests in nation building emphasized the delimitation of archaeological "cultures" to trace the history of ethnic groups (e.g., Bambara) and language families (e.g., Bantu) from the ethnographic present into a precolonial past (de Maret 2005; MacEachern 1998; Stahl 1999a). Across much of the southern half of the continent, the association of historical linguistic evidence with pottery has created the increasingly fraught assumption that pots equal ethnic groups (Ashley 2010; Croucher and Wynne-Jones 2006; Lane 2004). Over the past several decades, these approaches have become difficult to reconcile with growing recognition of the complex ways in which people construct and contest ethnicities and similar forms of social boundaries across Africa (e.g., Amselle and M'Bokolo 1985; Chrétien and Prunier 2003; Kopytoff 1987; Lentz 1995). Many anthropologists and historians now appreciate that ethnic affinities may coalesce around shared histories and cultural dispositions, even as they inevitably remain somewhat negotiable where people call attention to or away from these histories and dispositions in actual practices of identification.

As a result, archaeologists have turned their attention to how material practices become enrolled into ethnic identities today, with an eye towards understanding their negotiation and reproduction in the past (see discussion in Jones 1997). Moving beyond an uncritical view of household artifacts as emblems of primordial cultural difference, scholars have considered how people past and present actively negotiate ethnic boundaries through the use and display of pottery, iron tools, textiles, grinding stones, and other craft products in their everyday lives (e.g., Cruz 2011; David et al. 1991; Larick 1991; Pikirayi 2007; Richard and MacDonald 2014; Stahl 1991; Wiessner 1983; Wynne-Jones 2007). Meanwhile, ethnoarchaeological and archaeological studies have explored how people maintain and transform ethnic identities through techniques of craft production variously shaped by physical geography, embodied habits, learning contexts, and social networks (e.g., Childs 1991; Dietler and Herbich 1998; Gosselain 2000; Mayor 2010; Sall 2005). Although foodways have figured in the study of social boundaries among foragers, pastoralists, and farmers in Africa (Kusimba and Kusimba 2003; Smith 1998), a growing number of studies reveal how techniques of food preparation and consumption also play into the negotiation of ethnic and other regional identities (e.g., Ashley 2010; Lyons 2007; MacLean and Insoll 1999). Where these craft 
and culinary practices recursively shape social structures and institutions, they also give archaeology unique insight into how ethnic boundaries arise and change in relation to broader historical processes, such as the global entanglements described in the next section.

Alongside a more nuanced study of boundaries between African societies, the past two decades have seen anthropologists and historians move to critically examine the arrangements of statuses within them, particularly the seemingly paradoxical social construct of caste (e.g., Conrad and Frank 1995; Tamari 2005). On the one hand, this challenges the use of "caste" to translate local terms for the diverse array of endogamous craft-producing groups found in many parts of East and West Africa (Tamari 1991; Todd 1977). On the other hand, caste continues to provide a useful frame for comparing the historical processes by which occupational specialists in some parts of the world became excluded from marriage, commensality, and even physical contact with other members of their societies (Smith 2012). While archaeology has the potential to explore castes as historical processes, this entails a careful consideration of any correspondence between not just craft specialization and the social identities of craft producers, but as Logan and Cruz (this issue) suggest, a more nuanced understanding of the broader taskscapes in which they operate.

In this regard, those culinary practices inscribed in the archaeological record can offer additional lines of evidence for the social status, identities, and powers of craftspeople. John Arthur's ethnoarchaeological study of caste status in Gamo society of Ethiopia (this issue), for example, describes the material traces of full-time specialized production of ground stones and pots by endogamous groups of craftspeople historically excluded from land ownership. The relatively low status of these craftspeople, which actually differs from community to community, finds expression in their limited production, and presumably consumption, of luxury foods such as milk and beer using, of course, grindstones and pots. Elsewhere in Ethiopia, the perception that some craftspeople in the Tigray highlands are impure or dangerous arises, in part, from what they do eat. According to Lyons (this issue), endogamous groups of blacksmiths consume people, both indirectly through symbolic associations between themselves and certain foods and directly through sorcery, while potters consume clay, and with it the fertility of the land. Importantly, non-caste individuals who choose to pursue potting and smithing for economic reasons do not inherit these same metaphorical appetites and therefore do not experience the same degree of marginalization and stigma as casteborn artisans. Here again, the low status ascribed to craftspeople finds clear expression in the materiality and discourse surrounding culinary practices. Lyons' paper also offers a caution against simplistic correlations between archaeological evidence for craft production and interpretations of caste status, even where these latter have deep historical precedence.

In short, we contend that comparing craft and culinary practices has a central role to play in building alternative frameworks for understanding past sociality, by tracing the historical processes in which modern social forms developed, and perhaps in the future by continuing to question and redefine our concept of social groups to include more nuanced formations like communities of practice (see discussion by Stahl, this issue). This approach "offers a two-way bridge between the development of knowledgeable skill and identity - the production of persons - and the production and reproduction of communities of practice" (Lave 1991:68). Building on the growing ethnoarchaeological 
literature on situated learning of crafting (e.g., Gelbert 2003; Gosselain 2008; Roux 2007), greater attention to the acquisition of culinary techniques could help to flesh out the ways in which diverse subjectivities are understood and embodied in different historical contexts.

\section{Theme 4: Political Economy}

The diverse ways in which political status maps onto craft production point to a profound connection between identity and political economy in many African contexts. While accumulation and control over surplus foods and craft goods have long been considered essential ingredients of political complexity (e.g., D'Altroy and Earle 1985), the creative "composition" of material and non-material resources, including people with diverse technical skills and cultural knowledge, was vital to the emergence of diverse precolonial polities across Africa (Guyer and Belinga 1995). As nicely elaborated by a number of scholars (e.g., Fleisher and Wynne-Jones 2010; McIntosh 1999; Monroe 2013), the historical production of power and authority at local, regional, and global scales may have depended less on the surplus production of wealth and staple goods and more on the social identities and cultural values perpetuated through craft and culinary practices involving consumption and exchange.

Consumption has long been a marker of political power, and archaeologists often rely on the presence of luxury foods and goods as well as fancy serving wares to trace the presence of elites (Hastorf 2003; van der Veen 2003). Political status may be expressed or negotiated through consumption events known as feasts, where large amounts of food, drink, and serving vessels are consumed and elaborate preparation techniques may be used (Dietler 2001; Hayden and Villeneuve 2011). What are considered "special" or feast-quality foods differ cross-culturally. For example, in modern West Africa, de Garine (1997) suggests that "taste" is defined by access to large quantities of food rather than new or exotic foods. Cameron Monroe and Anneke Janzen (this issue) use historical documents to define "elite" or "desired" foods in seventeenth-nineteenth-century Benin. There, large and rarely captured animals mark special consumption events. Who supplies the food and drink may implicate the nature of local hierarchies; for example in give-away feasts, an individual or leader provides all of the food and drink to patrons, with expectations that this gift is reciprocated, in labor or in kind (Dietler 2001). Other types of feast, such as the "potluck" style meals also described by Monroe and Janzen, are suggestive of different, and perhaps non-reciprocal, kinds of relationships between provider and receiver. Feasting provides a powerful and recognizable lens through which to view political negotiation, but care must be taken to interpret such contexts in African terms, where "surplus" and "special food" (and indeed "hierarchy," McIntosh 1999) may be defined very differently. As Liza Gijanto and Sarah Walshaw (this issue) describe for eighteenth-century Gambia, contexts that were marked by rapid deposition and different kinds of foods were differentiated from slowly deposited contexts with mixed contents that likely represent daily accumulations. These special contexts could either be interpreted as evidence of feasts, as refuse from a different cultural group, such as the Europeans occupying 
the site at that time, or as a way to reconcile foreign influences at the local level (e.g., Fleisher 2010). As noted above, disentangling the complexities of African feasting practices is greatly aided by cross-comparison of craft and culinary residues.

Trade and exchange, as historical processes and social practices (e.g., Bauer and Agbe-Davies 2010), have undoubtedly shaped local African engagements with global political economies and associated processes often described as acculturation, hybridization, syncretism, and creolization (e.g., Haviser and MacDonald 2008; Kelly 1997; LaViolette 2008; Mitchell 2005; Ogundiran and Falola 2007; Stahl 1999b, 2001). In West Africa, research in this vein has tended to focus on the circulation of objects deployed in practices of destruction and social distinction-weapons, slaves, textiles, jewelry, alcohol, and so forth (Ogundiran 2002; Richard 2010; Stahl 2002)—whereas the intermingling and diffusion of locally made goods like food, pottery, and iron has long been a focus in eastern and southern Africa (e.g., Kusimba and Kusimba 2003; LaViolette and Fleisher 2005; see Stahl 2001; Stahl et al. 2008 for West African examples). The exchange of goods, and associated practical knowledge, is often critical to understanding how people within local communities experienced processes of contact and entanglement according to gender, age, kinship, and status (e.g., Lightfoot et al. 1998; Silliman 2001). Along the Swahili coast, imported crafts and food helped establish a distinct cosmopolitan identity (LaViolette 2008). Later on in West Africa, Atlantic trade brought industrially produced crafts like iron goods and metal pots, thereby eroding the local production of these goods and impacting the social status of craft producers (Goucher 1981). Similarly, the Atlantic introduction of American crops (e.g., maize and cassava) had variable impacts on local subsistence economies, yet we know little about the political, economic, and social mechanisms by which these foods were adopted (see Gijanto and Walshaw, Logan and Cruz, this issue; Logan 2012; McCann 2005). From even these limited examples, it is clear that processes of global entanglement were not unidirectional but provided a range of possible opportunities across space and time. Following upon the themes addressed above, a comparative approach to the exchange and transmission of craft and culinary practices may further help to examine the ways that people of different gender, ethnicity, and status affiliations in Africa have experienced and participated in an increasingly global political economy over the past two millennia.

\section{Organization of Special Issue}

The organization of this special issue has two overlapping parts: four papers that are primarily ethnoarchaeological in scope (Grillo, Arthur, Lyons, and Logan and Cruz) and four papers that are primarily archaeological (Gokee, Monroe and Janzen, Gijanto and Walshaw, and Gifford-Gonzalez). Two of these papers connect ethnoarchaeological and archaeological data (Logan and Cruz and Gifford-Gonzalez). We hope this juxtaposition highlights the value of historicizing ethnographic "traditions" on the one hand and socializing archaeological "cultures" on the other. The ethnoarchaeological section moves outwards in scale from the object to the taskscape to illustrate the many ways, times, and places in which craft and culinary practice can intersect. Grillo starts with one object class - pottery - and works outwards to document the multiple uses and meanings to which pottery is put, questioning simplistic assumptions about the 
relationship between ceramics and sedentary life. Arthur "scales up" to examine the chaines opératoires and life cycles of multiple kinds of culinary tools and luxury foods that demarcate boundaries between socioeconomic groups in Ethiopia. Elsewhere in Ethiopia, Lyons focuses on the craft specialists themselves as representing different iterations of personhood, in this case shunned actors in liminal zones. Finally, Logan and Cruz scale up even further to look at the taskscapes in which men and women operate, considering how farming, food, and crafting schedules and techniques overlap with each other over the last few centuries in Banda, Ghana.

These ethnoarchaeological studies provide a range of possible scales or cross-over points at which archaeologists can examine craft and culinary practice, though the unique challenges of archaeology redefine the units of comparison to that of deposit, site, or region. Similar to the scale used by Logan and Cruz, Gokee considers assemblage-wide patterns of pottery production and use to address the role of gender and ethnicity in defining ceramic and culinary variability at sites in the Upper Senegal region. Two papers focus on feasting in historically documented periods but with different results. As described above, Monroe and Janzen focus on specific palace contexts in Benin where historical documentation provides some indication of what is considered elite food. In contrast, Gijanto and Walshaw compare ceramics and plant and animal remains across a larger variety of context types in a multicultural landscape, leading to multiple possible interpretations. In both cases, the comparison of both craft and culinary elements leads to different interpretations than were assumed based on just one data type. Gifford-Gonzalez rounds out these case studies by taking us through the end of the meal and back to the "deposit" by examining variation in depositional practice across time and cultural groups in East and West Africa. Her cross-period and crosscultural examination highlights varied perceptions of what counts as refuse and "proper" discard, processes which structure deposits and build community at the same time. Finally, Ann Stahl concludes this issue with a discussion that both evaluates critically the contributions of individual papers to the themes outlined here, and situates a comparative approach to craft and culinary practice in Africa within the broader theoretical and methodological move to foreground overlapping relations_-social, temporal, spatial—as objects of archaeological inquiry.

The papers in this special issue of the African Archaeological Review showcase the array of theoretical, methodological, and topical themes potentially expanded through a comparative approach to craft and culinary practices in African archaeology and ethnoarchaeology. Some of these themes, such as gender and the inseparability of crafts and cuisine in everyday life, have relevance beyond places and periods within Africa. Other themes, such as ethnicity and caste, have greater specificity to our regional emphasis on West Africa and Eastern Africa. All of these papers highlight the potential for a comparative approach to crafts and foodways to expand upon old themes in African archaeology and open the doors to new ones. Drawing upon an evergrowing body of material and historical evidence, methodological advances, and the shifting terrain of theoretical perspectives, the time seems ripe to reevaluate the possible contribution of studies of crafts and foodways to understanding African pasts, presents, and perhaps futures. 
Acknowledgments We gratefully acknowledge the participants in this special issue as well as those who participated in the 2012 SAfA session but were unable to contribute a paper. We thank Ann Stahl for her helpful feedback on the session and for writing the discussion piece, Nic David for suggesting that we produce an edited issue based on the session, and especially Adria LaViolette for her support in bringing this issue together.

\section{References}

Amblard, S., \& Pernès, J. (1989). The identification of cultivated pearl millet (Pennisetum) amongst plant impressions on pottery from Oued Chebbi (Dhar Oualata, Mauritania). African Archaeological Review, 7, $117-126$.

Amselle, J.-L., \& M'Bokolo, E. (1985). Au coeur de l'ethnie: Ethnies, tribalisme, et État en Afrique. Paris: La Découverte.

Appadurai, A. (1986). Introduction: Commodities and the politics of value. In A. Appadurai (Ed.), The social life of things: Commodities in cultural perspective (pp. 3-63). Cambridge: Cambridge University Press.

Arthur, J. W. (2006). Living with pottery: Ethnoarchaeology among the Gamo of southwest Ethiopia. Salt Lake City: University of Utah Press.

Arthur, K. W. (2010). Feminine knowledge and skill reconsidered: Women and flaked stone tools. American Anthropologist, 112(2), 228-243.

Ashley, C. Z. (2010). Towards a socialised archaeology of ceramics in Great Lakes Africa. African Archaeological Review, 27(2), 135-163.

Atalay, S., \& Hastorf, C. (2006). Food, meals, and daily practice: Food habitus at Neolithic Çatalhöyük. American Antiquity, 71(2), 283-319.

Atherton, J. H. (1983). Ethnoarchaeology in Africa. African Archaeological Review, 1, 75-104.

Barham, L., \& Mitchell, P. (2008). The first Africans: African archaeology from the earliest tool makers to most recent foragers. Cambridge: Cambridge University Press.

Bauer, A. A., \& Agbe-Davies, A. S. (Eds.). (2010). Social archaeologies of trade and exchange: Exploring relationships among people, places, and things. Walnut Creek, CA: Left Coast Press.

Binford, L. R. (1962). Archaeology as anthropology. American Antiquity, 28(2), 217-225.

Breunig, P., \& Neumann, K. (2002). From hunters and gatherers to food producers: New archaeological and archaeobotanical evidence from the West African Sahel. In F. A. Hassan (Ed.), Droughts, food and culture: Ecological change and food security in Africa's later prehistory (pp. 123-156). New York: Kluwer Academic/Plenum Publishers.

Brumfiel, E. (1992). Breaking and entering the ecosystem-Gender, class, and faction steal the show. American Anthropologist, 94(3), 551-567.

Brumfiel, E. (2006). Cloth, gender, continuity, and change: Fabricating unity in anthropology. American Anthropologist, 108(4), 862-877.

Brumfiel, E. M., \& Robin, C. (2008). Gender, households, and society: An introduction. In E. M. Brumfel \& C. Robin (Eds.), Gender, households, and society: Unraveling the threads of past and present (pp. 1-16). Archaeological Papers of the American Anthropological Association 18. Washington, DC: American Anthropological Association.

Casey, J. (2005). Holocene occupations of the forest and savanna. In A. B. Stahl (Ed.), African archaeology: A critical introduction (pp. 225-248). London: Blackwell.

Childe, V. G. (1951). Social evolution. London: C. A. Watts.

Childs, S. T. (1991). Style, technology, and iron smelting furnaces in Bantu-speaking Africa. Journal of Anthropological Archaeology, 10(4), 332-359.

Childs, S. T., \& Killick, D. (1993). Indigenous African metallurgy: Nature and culture. Annual Review of Anthropology, 22, 317-337.

Chrétien, J.-P., \& Prunier, G. (Eds.). (2003). Les ethnies ont une histoire. Paris: Éditions Karthala.

Clark, J. L. (2011). The evolution of human culture during the later Pleistocene: Using fauna to test models on the emergence and nature of "modern" human behavior. Journal of Anthropological Archaeology, 30(3), 273-291.

Clark, J. D., \& Brandt, S. A. (Eds.). (1984). From hunters to farmers: The causes and consequences of food production in Africa. Berkeley: University of California Press.

Clarke, D. L. (1978). Analytical archeology. New York: Methuen \& Co.

Conkey, M. W., \& Spector, J. (1984). Archaeology and the study of gender. Advances in Archaeological Method and Theory, 7, 1-38. 
Conrad, D. C., \& Frank, B. E. (Eds.). (1995). Status and identity in West Africa: Nyamakalaw of Mande. Bloomington: Indiana University Press.

Costin, C. L., \& Wright, R. P. (Eds.). (1998). Craft and social identity. Archaeological Papers of the American Anthropological Association, 8. Washington, DC: American Anthropological Association.

Croucher, S. K. (2007). Clove plantations on nineteenth-century Zanzibar: Possibilities for gender archaeology in Africa. Journal of Social Archaeology, 7(3), 302-324.

Croucher, S. K., \& Wynne-Jones, S. (2006). People, not pots: Locally produced ceramics and identity on the nineteenth-century East African Coast. The International Journal of African Historical Studies, 39(1), $107-124$.

Cruz, M. D. (2011). "Pots are pots, not people:" Material culture and ethnic identity in the Banda Area (Ghana), nineteenth and twentieth centuries. Azania, 46(3), 336-357.

D'Altroy, T. N., \& Earle, T. K. (1985). Staple finance, wealth finance, and storage in the Inka political economy. Current Anthropology, 26(2), 187-206.

D’Andrea, A. C., \& Wadge, P. (2011). T'ef (Eragrostis tef): A legacy of pastoralism? In A. G. Fahmy, S. Kahlheber, \& A. C. D'Andrea (Eds.), Windows on the African past: Current approaches to African archaeobotany (pp. 225-241). Reports in African Archaeology 3. Frankfurt: Africa Magna Verlag.

David, N. (1998). The ethnoarchaeology and field archaeology of grinding at Sukur, Adamawa State, Nigeria. African Archaeological Review, 15(1), 13-63.

David, N., \& Hennig, H. (1972). The ethnography of pottery: A Fulani case seen in archaeological perspective. Reading, MA: Addison-Wesley.

David, N., Sterner, J., \& Gavua, K. (1988). Why pots are decorated. Current Anthropology, 29(3), 365-389.

David, N., Gavua, K., MacEachern, S., \& Sterner, J. (1991). Ethnicity and material culture in north Cameroon. Canadian Journal of Archaeology, 15, 171-177.

De Certeau, M. (1984). The practice of everyday life. Berkeley: University of California Press.

De Garine, I. (1997). Food preferences and taste in an African perspective: A word of caution. In H. Macbeth (Ed.), Food preferences and taste: Continuity and change (pp. 187-199). Providence: Berghahn Books.

de Maret, P. (2005). From pottery groups to ethnic groups in Central Africa. In A. B. Stahl (Ed.), African archaeology: A critical introduction (pp. 420-440). Malden, MA: Blackwell.

DeCorse, C. R. (Ed.). (2001). West Africa during the Atlantic slave trade: Archaeological perspectives. London: Leicester University Press.

Díaz-Andreu, M., Lucy, S., Babić, S., \& Edwards, D. N. (Eds.). (2005). The archaeology of identity: Approaches to gender, age, status, ethnicity, and religion. New York: Routledge.

Dietler, M. (2001). Theorizing the feast: Rituals of consumption, commensal politics, and power in African contexts. In M. Dietler \& B. Hayden (Eds.), Feasts: Archaeological and ethnographic perspectives on food, politics, and power (pp. 65-114). Tuscaloosa: University of Alabama Press.

Dietler, M., \& Herbich, I. (1998). Habitus, techniques, style: An integrated approach to the social understanding of material culture and boundaries. In M. T. Stark (Ed.), The archaeology of social boundaries (pp. 232-263). Washington, DC: Smithsonian Institution Press.

Dobres, M.-A., \& Robb, J. (Eds.). (2000). Agency in archaeology. New York: Routledge.

Dominguez-Rodrigo, M. (2002). Hunting and scavenging by early humans: The state of the debate. Journal of World Prehistory, 16(1), 1-54.

Flannery, K. V. (1972). The cultural evolution of civilizations. Annual Review of Ecology and Systematics, 3, $399-425$.

Fleisher, J. (2010). Rituals of consumption and the politics of feasting on the Eastern African Coast, AD 7001500. Journal of World Prehistory, 23(4), 195-217.

Fleisher, J., \& Wynne-Jones, S. (2010). Authorisation and the process of power: The view from African archaeology. Journal of World Prehistory, 23(4), 177-193.

Fogelin, L. (2007). Inference to the best explanation: A common and effective form of archaeological reasoning. American Antiquity, 72(4), 603-625.

Gallay, A., \& Huysecom, E. (1989). Ethnoarchéologie africaine. Genève: Université de Genève.

Gelbert, A. (2003). Traditions céramiques et emprunts techniques dans la vallée du fleuve Sénégal. Paris: Éditions de la Maison des Sciences de l'Homme.

Gero, J. M., \& Conkey, M. W. (Eds.). (1991). Engendering archaeology: Women and prehistory. Malden, MA: Blackwell.

Gijanto, L. (2011). Socio-economic interaction and ceramic aesthetic: Understanding West African ceramic production and use in context. Azania, 46(3), 250-268.

González-Ruibal, A. (2006). The dream of reason: An archaeology of the failures of modernity in Ethiopia. Journal of Social Archaeology, 6(2), 175-201. 
Gosden, C. (2004). Archaeology and colonialism: Cultural contact from 5000 BC to the present. Cambridge: Cambridge University Press.

Gosselain, O. P. (2000). Materializing identities: An African perspective. Journal of Archaeological Method and Theory, 7(3), 187-217.

Gosselain, O. P. (2008). Mother Bella was not a Bella: Inherited and transformed traditions in southwestern Niger. In M. T. Stark, B. J. Bowser, \& L. Horne (Eds.), Cultural transmission and material culture: Breaking down boundaries (pp. 150-177). Tucson: University of Arizona Press.

Gosselain, O. P. (2010). Exploring the dynamics of African pottery cultures. In R. Barndon, A. Engevik, \& I. Øye (Eds.), The archaeology of regional technologies: Case studies from the Palaeolithic to the Age of the Vikings (pp. 193-224). Lewiston, NY: Edwin Mellen Press.

Goucher, C. L. (1981). Iron is iron 'til it is rust: Trade and ecology in the decline of West African ironsmelting. The Journal of African History, 22(2), 179-189.

Gumerman, G. J. (1997). Food and complex societies. Journal of Archaeological Method and Theory, 4(2), $105-139$.

Guyer, J., \& Belinga, S. M. E. (1995). Wealth in people as wealth in knowledge: Accumulation and composition in Equatorial Africa. The Journal of African History, 36(1), 91-120.

Haaland, R. (2007). Porridge and pot, bread and oven: Food ways and symbolism in Africa and the Near East from the Neolithic to present. Cambridge Archaeological Journal, 17(2), 165-182.

Haaland, R. (2012). Changing food ways as indicators of emerging complexity in Sudanese Nubia: From Neolithic agropastoralists to the Meroitic civilisation. Azania, 47(3), 327-343.

Hamon, C., \& Le Gall, V. (2013). Millet and sauce: The uses and functions of querns among the Minyanka (Mali). Journal of Anthropological Archaeology, 32(1), 109-121.

Hastorf, C. A. (2003). Andean luxury foods: Special food for the ancestors, deities and the elite. Antiquity, 77(297), 545-554.

Haviser, J. B., \& MacDonald, K. C. (Eds.). (2008). African re-genesis. Walnut Creek, CA: Left Coast Press.

Hawkes, C. (1954). Archaeological theory and method: Some suggestions from the Old World. American Anthropologist, 56(2), 155-168.

Hayden, B., \& Villeneuve, S. (2011). A century of feasting studies. Annual Review of Anthropology, 40, 433449.

Hegmon, M. (2003). Setting theoretical egos aside: Issues and theory in North American archaeology. American Antiquity, 68(2), 213-243.

Henrickson, E. F., \& McDonald, M. M. A. (1983). Ceramic forms and function: An ethnographic search and an archaeological application. American Anthropologist, 85(3), 630-643.

Herbert, E. W. (1993). Iron, gender, and power: Rituals of transformation in African societies. Bloomington: Indiana University Press.

Hildebrand, E. A. (2003). Motives and opportunities for domestication: An ethnoarchaeological study in southwest Ethiopia. Journal of Anthropological Archaeology, 22(4), 358-375.

Ingold, T. (1993). The temporality of the landscape. World Archaeology, 25(2), 152-174.

Insoll, T. (2010). Talensi animal sacrifice and its archaeological implications. World Archaeology, 42(2), 231244.

Insoll, T., Kankpeyeng, B., \& MacLean, R. (2009). The archaeology of shrines among the Tallensi of northern Ghana: Materiality and interpretive relevance. In A. C. Dawson (Ed.), Shrines in Africa: History, politics, and society (pp. 41-70). Calgary: University of Calgary Press.

Johnson, M. H. (2011). On the nature of empiricism in archaeology. Journal of the Royal Anthropological Institute (N.S.), 17, 764-787.

Jones, S. (1997). The archaeology of ethnicity. London: Routledge.

Jousse, H. (2006). What is the impact of Holocene climatic changes on human societies? Analysis of West African Neolithic populations dietary customs. Quaternary International, 151(1), 63-73.

Joyce, R. A. (2000). Girling the girl and boying the boy: The production of adulthood in ancient Mesoamerica. World Archaeology, 31(3), 473-483.

Joyce, R. A. (2008). Practice in and as deposition. In B. J. Mills \& W. H. Walker (Eds.), Memory work: Archaeologies of material practices (pp. 25-39). Santa Fe: School of American Research Press.

Kelly, K. G. (1997). The archaeology of African-European interaction: Investigating the social roles of trade, traders, and the use of space in the seventeenth- and eighteenth-century Hueda kindom, Republic of Benin. World Archaeology, 28(3), 351-369.

Kent, S. (Ed.). (1998). Gender in African prehistory. London: Altamira Press.

Killick, D. (2004). Review essay: What do we know about African iron-working? Journal of African Archaeology, 2(1), 97-112. 
Knappett, C. (2011). An archaeology of interaction: Network perspectives on material culture and society. Oxford: Oxford University Press.

Kopytoff, I. (1986). The cultural biography of things: Commoditization as a process. In A. Appadurai (Ed.), The social life of things: Commodities in cultural perspective (pp. 64-91). Cambridge: Cambridge University Press.

Kopytoff, I. (Ed.). (1987). The African frontier: The reproduction of traditional African societies. Bloomington: Indiana University Press.

Kusimba, S. B. (2003). African foragers: Environment, technology, interactions. Walnut Creek, CA: AltaMira Press.

Kusimba, C. M., \& Kusimba, S. B. (2003). East African archaeology: Foragers, potters, smiths, and traders. Philadelphia: University of Pennsylvania Museum of Archaeology and Anthropology.

Lane, P. (2004). The 'moving frontier' and the transition to food production in Kenya. Azania, 34(1), 243-264.

Larick, R. (1991). Warriors and blacksmiths: Mediating ethnicity in East African spears. Journal of Anthropological Archaeology, 10(4), 299-331.

Lave, J. (1991). Situated learning in communities of practice. Perspectives on Socially Shared Cognition, 2(1), 63-82.

LaViolette, A. (2000). Ethno-archaeology in Jenné, Mali: Craft and status among smiths, potters and masons. BAR International Series 838. Oxford: Archaeopress.

LaViolette, A. (2008). Swahili cosmopolitanism in Africa and the Indian Ocean world, AD 600-1500. Archaeologies, 4(1), $24-49$.

LaViolette, A., \& Fleisher, J. (2005). The archaeology of sub-Saharan urbanism: Cities and their countrysides. In A. B. Stahl (Ed.), African archaeology: A critical introduction (pp. 327-352). Malden, MA: Blackwell Publishing.

Lentz, C. (1995). 'Tribalism' and ethnicity in Africa: A review of four decades of anglophone research. Cahiers des Sciences Humaines, 31(2), 303-328.

Lightfoot, K. G., Martinez, A., \& Schiff, A. M. (1998). Daily practice and material culture in pluralistic social settings: An archaeological study of culture change and persistence from Fort Ross, California. American Antiquity, 63(2), 199-222.

Logan, A. L. (2012). A history of food without history: Food, trade, and environment in west-central Ghana in the second millennium AD. Unpublished PhD dissertation. Ann Arbor: University of Michigan.

Lyons, D. (2007). Integrating African cuisines: Rural cuisine and identity in Tigray, highland Ethiopia. Journal of Social Archaeology, 7(3), 346-371.

Lyons, D., \& D’Andrea, A. C. (2003). Griddles, ovens, and agricultural origins: An ethnoarchaeological study of bread baking in highland Ethiopia. American Anthropologist, 105(3), 515-530.

MacEachern, S. (1996). Foreign countries: The development of ethnoarchaeology in sub-Saharan Africa. Journal of World Prehistory, 10(3), 243-304.

MacEachern, S. (1998). Scale, style, and cultural variation: Technological traditions in the northern Mandara Mountains. In M. T. Stark (Ed.), The archaeology of social boundaries (pp. 107-131). Washington, DC: Smithsonian Institution Press.

MacEachern, S. (2005). Two thousand years of West African history. In A. B. Stahl (Ed.), African archaeology: A critical introduction (pp. 441-466). Malden, MA: Blackwell Publishing.

MacLean, R., \& Insoll, T. (1999). The social context of food technology in Iron Age Gao, Mali. World Archaeology, 31(1), 78-92.

MacLean, R., \& Insoll, T. (2003). Archaeology, luxury and the exotic: The examples of Islamic Gao (Mali) and Bahrain. World Archaeology, 34(3), 558-570.

Manning, K., Pelling, R., Higham, T., Schwenniger, J.-L., \& Fuller, D. Q. (2011). 4500-year old domesticated pearl millet (Pennisetum glaucum) from the Tilemsi Valley, Mali: New insights into an alternative cereal domestication pathway. Journal of Archaeological Science, 38(2), 312-322.

Mayor, A. (2010). Ceramic traditions and ethnicity in the Niger Bend, West Africa. Ethnoarchaeology, 2(1), 5-48.

McBrearty, S., \& Brooks, A. S. (2000). The revolution that wasn't: A new interpretation of the origin of modern human behavior. Journal of Human Evolution, 39(5), 453-563.

McCall, G. S., \& Thomas, J. T. (2012). Still Bay and Howiesons Poort foraging strategies: Recent research and models of culture change. African Archaeological Review, 29(1), 7-50.

McCann, J. (2005). Maize and grace: Africa's encounter with a New World crop, 1500-2000. Cambridge, MA: Harvard University Press.

McIntosh, S. K. (1995). Pottery. In S. K. McIntosh (Ed.), Excavations at Jenné-jeno, Hambarketolo, and Kaniana (Inland Niger Delta, Mali), the 1981 season (pp. 130-213). Berkeley: University of California Press. 
McIntosh, S. K. (Ed.). (1999). Beyond chiefdoms: Pathways to complexity in Africa. Cambridge: Cambridge University Press.

McIntosh, S. K., \& McIntosh, R. J. (1988). From stone to metal: New perspectives on the later prehistory of West Africa. Journal of World Prehistory, 2(1), 89-133.

McNaughton, P. R. (1988). The Mande blacksmiths: Knowledge, power, and art in West Africa. Bloomington: Indiana University Press.

Mills, B. J., \& Walker, W. H. (Eds.). (2008). Memory work: Archaeologies of material practices. Santa Fe: School for Advanced Research Press.

Minar, C. J., \& Crown, P. (2001). Learning and craft production: An introduction. Journal of Anthropological Research, 57(4), 369-380.

Mitchell, P. (2005). African connections: Archaeological perspectives on Africa and the wider world. Walnut Creek, CA: AltaMira Press.

Monroe, J. C. (2013). Power and agency in precolonial African states. Annual Review of Anthropology, 42, 17-35.

Neumann, K. (2003). The late emergence of agriculture in sub-Saharan Africa: Archaeological evidence and ecological considerations. In K. Neumann, A. Butler, \& S. Kahlheber (Eds.), Food, fuel, and fields: Progress in African archaeobotany (pp. 71-94). Africa Praehistorica 15. Cologne: Heinrich Barth Institut.

Norman, N. L. (2010). Feasts in motion: Archaeological views of parades, ancestral pageants, and sociopolitical process in the Hueda Kingdom, 1650-1727 AD. Journal of World Prehistory, 23(4), 239-254.

O’Connell, J. F., Hawkes, K., \& Blurton Jones, N. (1988). Hadza hunting, butchering, and bone transport and their archaeological implications. Journal of Anthropological Research, 44(2), 113-161.

Ogundiran, A. (2002). Of small things remembered: Beads, cowries, and cultural translations of the Atlantic experience in Yorubaland. International Journal of African Historical Studies, 35(2/3), 427-457.

Ogundiran, A., \& Falola, T. (Eds.). (2007). Archaeology of Atlantic Africa and the African Diaspora. Bloomington: Indiana University Press.

Pauketat, T. R. (Ed.). (2001a). The archaeology of traditions: Agency and history before and after Columbus. Gainesville: University Press of Florida.

Pauketat, T. R. (2001b). Practice and history in archaeology: An emerging paradigm. Anthropological Theory, 1(1), 73-98.

Pikirayi, I. (2007). Ceramics and group identities: Towards a social archaeology in Southern African Iron Age ceramic studies. Journal of Social Archaeology, 7(3), 286-301.

Richard, F. G. (2010). Recharting Atlantic encounters: Object trajectories and histories of value in the Siin (Senegal) and Senegambia. Archaeological Dialogues, 17(1), 1-27.

Richard, F. G. (2011). Materializing poverty: Archaeological reflections from the postcolony. Historical Archaeology, 45(3), 166-182.

Richard, F. G., \& MacDonald, K. C. (Eds.). (2014). Ethnic ambiguity and the African past: Materiality, history, and the shaping of cultural identities. Walnut Creek, CA: Left Coast Press.

Roddick, A. P. (2013). Temporalities of the formative period Taraco Peninsula, Bolivia. Journal of Social Archaeology, 13(3), 287-309.

Roux, V. (2007). Ethnoarchaeology: A non historical science of reference necessary for interpreting the past. Journal of Archaeological Method and Theory, 14(2), 153-178.

Rowlands, M. J., \& Warnier, J.-P. (1996). Magical iron technology in the Cameroon Grassfields. In M. J. Arnoldi, C. M. Geary, \& K. L. Hardin (Eds.), African material culture (pp. 51-72). Bloomington: Indiana University Press.

Sall, M. (2005). Traditions céramiques, identités et peuplement en Sénégambie: Ethnographie comparée et essai de reconstitution historique. BAR International Series 1407. Oxford: Archaeopress.

Schmidt, P. R. (Ed.). (1996). The culture and technology of African iron production. Gainesville: University of Florida Press.

Shaw, T., Sinclair, P., Andah, B., \& Okpoko, A. (Eds.). (1993). The archaeology of Africa: Food, metals and towns. New York: Routledge.

Silliman, S. (2001). Agency, practical politics, and the archaeology of culture contact. Journal of Social Archaeology, 1(2), 190-209.

Smith, A. B. (1998). Keeping people on the periphery: The ideology of social hierarchies between hunters and herders. Journal of Anthropological Archaeology, 17(2), 201-215.

Smith, A. (2004). The end of the essential archaeological subject. Archaeological Dialogues, 11(1), 1-20.

Smith, M. L. (2006). The archaeology of food preference. American Anthropologist, 108(3), 480-493.

Smith, M. L. (2012). Caste as a cooperative economic entitlement strategy in complex societies of the Indian subcontinent and sub-Saharan Africa. In D. Carballo (Ed.), Cooperation and collective action: Archaeological perspectives (pp. 275-297). Boulder: University Press of Colorado. 
Stahl, A. B. (1991). Ethnic style and ethnic boundaries: A diachronic case study from west-central Ghana. Ethnohistory, 38(3), 250-275.

Stahl, A. B. (1993). Concepts of time and approaches to analogical reasoning in historical perspective. American Antiquity, 58(2), 235-260.

Stahl, A. B. (1999a). Perceiving variability in time and space: The evolutionary mapping of African societies. In S. K. McIntosh (Ed.), Beyond chiefdoms: Pathways to complexity in Africa (pp. 39-55). Cambridge: Cambridge University Press.

Stahl, A. B. (1999b). The archaeology of global encounters viewed from Banda, Ghana. African Archaeological Review, 16(1), 5-81.

Stahl, A. B. (2001). Making history in Banda: Anthropological visions of Africa's past. Cambridge: Cambridge University Press.

Stahl, A. B. (2002). Colonial entanglements and the practices of taste: An alternative to logocentric approaches. American Anthropologist, 104(3), 827-845.

Stahl, A. B. (2004). Political economic mosaics: Archaeology of the last two millennia in tropical sub-Saharan Africa. Annual Review of Anthropology, 33, 145-172.

Stahl, A. B. (2008). Dogs, pythons, pots, and beads: The dynamics of shrines and sacrificial practices in Banda, Ghana, 1400-1900 CE. In B. J. Mills \& W. H. Walker (Eds.), Memory work: Archaeologies of material practices (pp. 159-186). Santa Fe: School for Advanced Research Press.

Stahl, A. B. (2010). Material histories. In D. Hicks \& M. Beaudry (Eds.), The Oxford handbook of material culture studies (pp. 148-170). Oxford: Oxford University Press.

Stahl, A. B., Cruz, M. D., Neff, H., Glascock, M. D., Speakman, R. J., Giles, B., et al. (2008). Ceramic production, consumption and exchange in the Banda area, Ghana: Insights from compositional analyses. Journal of Anthropological Archaeology, 27(3), 363-381.

Stark, M. T. (Ed.). (1998). The archaeology of social boundaries. Washington, DC: Smithsonian Institution Press.

Tamari, T. (1991). The development of caste systems in West Africa. Journal of African History, 32(2), 221250.

Tamari, T. (2005). Kingship and caste in Africa: History, diffusion and evolution. In D. Quigley (Ed.), The character of kingship (pp. 141-169). New York: Berg.

Todd, D. M. (1977). Caste in Africa? Africa Journal of the International African Institute, 47(4), $398-412$.

Twiss, K. (Ed.). (2007). The archaeology of food and identity. Center for archaeological investigations, occasional paper no. 34. Carbondale: Southern Illinois University.

Van der Veen, M. (2003). When is food a luxury? World Archaeology, 34(3), 405-427.

Vogel, J. O. (Ed.). (2000). Ancient African metallurgy. Walnut Creek, CA: Altamira Press.

Wadley, L. (1997). Our gendered past: Archaeological studies of gender in Southern Africa. Johannesburg: Witwatersrand University Press.

Wallaert-Pêtre, H. (2001). Learning how to make the right pots: Apprenticeship strategies and material culture. Journal of Anthropological Research, 57(4), 471-493.

Wendrich, W. (Ed.). (2012). Archaeology and apprenticeship: Body knowledge, identity, and communities of practice. Tucson: University of Arizona Press.

Wiessner, P. (1982). Beyond willow smoke and dogs' tails: A comment on Binford's analysis of huntergatherer settlement systems. American Antiquity, 47(1), 171-178.

Wiessner, P. (1983). Style and social information in Kalahari San projectile points. American Antiquity, 48(2), $253-276$.

Wylie, A. (1985). The reaction against analogy. Advances in Archaeological Method and Theory, 8, 63-111.

Wylie, A. (1989). Archaeological cables and tacking: The implications of practice for Bernstein's "options beyond objectivism and relativism.". Philosophy of the Social Sciences, 19, 1-18.

Wynne-Jones, S. (2007). It's what you do with it that counts. Journal of Social Archaeology, 7(3), 325-345. 